\title{
PENGARUH KEWENANGAN DAN PENGAMBILAN KEPUTUSAN TERHADAP EFEKTIVITAS MANAJERIAL KEPALA SEKOLAH MENENGAH ATAS DI JAKARTA UTARA
}

\author{
Siti Wahdatun Nuriah *
}

\begin{abstract}
The study aims to obtain empirical data about the presence or absence of a strong and weak linkage between the independent variable authority and decicion making with the dependent variable managerial effectiveness principle on senior high school North Jakarta. The research method used in this research is survey. The sample is 52 respondents taken by proporsional random sampling. The study was conducted to senior high school principlals in North Jakarta. The result of the study pointed out that: (1) there is a direct and significant influence of Authority with managerial effectiveness, (2) there is a direct and significant influence of decision making with managerial effectiveness and (3) there is a direct and significant influence authority with decision making.
\end{abstract}

Keywords : Authority, Decision making, Effectiveness, Managerial Effectiveness

\section{PENDAHULUAN}

Di era globalisasi ini dituntut keahlian kepemimpinan kepala sekolah yang harus terus di kembangkan seiring dengan perubahan-perubahan di bidang pendidikan. Salah satu perubahan yang mendasar dalam organisasi pendidikan adalah sistem manajemen yang sentralisasi diganti dengan sistem manajemen desentralisasi melalui Undangundang Nomor 32 Tahun 2004 tentang Pemerintahan Daerah. Hal ini menuntut perubahan berbagai komponen dalam organisasi sekolah dan juga gaya kepemimpinan kepala sekolah. Artinya dalam situasi tidak menentu, penuh dengan perubahan dan ketidakpastian d iperlukan keahlian manajerial seorang kepala sekolah yang baik, sekaligus dapat mengembangkan keahliannya dalam bidang kepemimpinan.

Desentralisasi pendidikan dapat dimaknai sebagai pemberian wewenang pemerintah pusat kepada pemerintah daerah, sehingga pemerintah daerah dapat pula memberikan wewenang yang penuh kepada setiap persekolahan untuk menerjemahkan tujuan pendidikan nasional dengan tidak mengabaikan karakteristik daerahnya masingmasing. Penyelenggaraan wewenang ini berimplikasi luas terhadap sistem penyelenggaraan pendidikan. Hal ini dapat dilihat dari diterapkannya manajemen pendidikan berbasis sekolah, sebagai konsekuensi logis implementasi otonomi sekolah. Era desentralisasi adalah era perubahan yang memberikan peluang besar kepada kepala sekolah untuk megembangkan nilai-nilai kepemimpinan manajerialnya. Kepala sekolah memiliki kewenangan untuk mengelola organisasi sekolahnya dengan kemandiriannya, yang akan meningkatkan kreativitas dan kecakapan kemampuan manajerialnya. Seperti kita ketahui kepala sekolah adalah seorang pimpinan dan manajer dari organ isasi sekolah yang dipimpinnya.

Ketidakberdayaan dan ketidakleluasaan kepala sekolah dalam mengembang kan kreativitas untuk mengelola dan mengalokasikansumber daya dan dana yang diperlukan dalam rangka meningkatkan mutu pendidikan dan pengajaran di sekolah merupakan salah satu faktor kurang efektifnya kerja manajerial kepala sekolah sebagai pimpinan dan manajer dalam mencapai tujuan pendidikan yang optimal. Para kepala sekolah

\footnotetext{
* Guru di SMPN 84 Jakarta Utara
} 
cenderung menerima apa adanya berbagai aturan yang ditetapkan oleh atasan, hal ini berakibat pada kurangnya kreativitas mereka dan tidak berani membuat keputusan ataupun melakukan terobosan untuk memajukan pendidikan di sekolah mereka. Padahal para manajer yang memiliki kewenangan yang relatif tinggi dapat menjalankan lebih banyak kemandirian dan dengan demikian memuaskan hasrat-hasrat mereka untuk ikut serta memecahkan masalah4. Kemandirian ini dapat menghasilkan kreativitas dan kecakapan manajerial, yang memberikan andil terhadap kemampuan beradaptasi serta pengembangan organisasi serta pengembangan organisasi dan pengembangan para manajer.

Kesempatan untuk turut serta dalam menentukan tujuan-tujuan bisa menjadi faktor yang positif. Kondisi yang ada agar para kepala sekolah mampu menentukan tujuan adalah adanya kewenangan untuk mengambil keputusan. Pengambilan keputusan didefinisikan secara universal sebagai pemilihan alternatif. Hal ini berhubungan dengan fungsi manajemen tradisional. Saat manajer merencanakan, mengelola dan mengontrol, mereka membuat keputusan. Oleh karena itu kemampuan manajerial kepala sekolah akan mempengaruhi efektivitas kerja kepala sekolah dan akan mempengaruhi keberhasilan dari tujuan pendidikan sekolah itu sendiri dan akan memberikan kontribusi yang penting bagi kemajuan pendidikan nasional.

Salah satu kemampuan manajerial kepemimpinan, yaitu pengambilan keputusan. Seorang pemimpin sebagian besar waktu dan perhatian, maupun pikirannya dipergunakan untuk mengkaji proses pengambilan keputusan. Keputusan dari seorang pemimpin tidak muncul secara tiba-tiba, tetapi berlangsung sebagai sebuah proses. Dalam kenyataannya proses itu mungkin terjadi dalam diri pemimpin sendiri. Mungkin pula ditetapkan dengan mengikutsertakan anggota organisasi sekolah. Sehubungan dengan itu secara konvensional harus diterima kenyataan bahwa pengambilan keputusan adalah wewenang pimpinan tertinggi dari sebuah organisasi. Dengan kata lain pengambilan keputusan yang akan diwujudkan menjadi kegiatan kelompok atau organisasi merupakan hak dan kewajiban pimpinan. Semakin tinggi posisi seseorang dalam kepemimpinan organisasi maka pengambilan keputusan menjadi tugas utama yang harus dilaksanakan. Perilaku dan cara pimpinan dalam pola pengambilan keputusan sangat mempengaruhi perilaku dan sikap dari para pengikutnya. Hal ini sangat menentukan kinerja organisasi sekolah untuk mencapai tujuannya.

Saat ini di Jakarta Utara ada beberapa Sekolah Menengah Atas Swasta yang terpaksa ditutup dan tidak lagi menerima siswa baru, dikarenakan pihak yayasan yang merasa bahwa Sekolah Menengah Atas tidak lagi berpotensi mendapatkan keuntungan. Namun ditengah situasi yang demikian, ada juga kepala sekolah yang berusaha mempertahankan keberadaan sekolahnya dengan meningkatkan efektivitas organisasi sekolah. Diantaranya dengan menggunakan wewenangnya sebagai kepala sekolah untuk turut mengambil keputusan bagi organisasi sekolah. Sehingga perlu diadakan penelitian tentang faktor-faktor yang mempengaruhi efektivitas manajerial Kepala Sekolah Menengah Swasta di Jakarta Utara. Banyak faktor yang mempengaruhi efektivitas manajerial kepala sekolah, termasuk diantaranya adalah kewenangan dan pengambilan keputusan. Karena begitu kompleknya masalah efektivitas manajerial kepala sekolah ini, maka penelitian ini akan menyoroti tentang pengaruh kewenangan dan pengambilan keputusan kepala sekolah terhadap efektivitas manajerial kepala sekolah di SMA Swasta di Jakarta Utara.

\section{Efektivitas Manajerial}


Dikatakan oleh Mullins (2005:260) "managerial effectiveness results from a combination of personal attributes and dimensions of the manager's job in meeting the demands of the situation, and satisfying the requirements of the organisation." Efektivitas manajerial adalah hasil dari kombinasi atribut pribadi dan dimensi pekerjaan manajer dalam memenuhi tuntutan situasi dan memuaskan persyaratan organisasi. Laurie J.Mullins mengatakan, In order to be effective, the manager must give attention to outputs of the jobto performance in terms of such factors as obtaining best possible results in the important areas of the organisation, optimising use of resources, incincreasing profitability, and attainment of the aims and objectives of the organisation. Menurut Mullins untuk menjadi efektif, manajer harus memberi perhatian kepada hasil kerja, terhadap faktor kinerja seperti dalam memperoleh hasil yang terbaik dalam bidang penting pada organisasi, mengoptimalkan penggunaan sumber daya, meningkatkan keuntungan, dan pencapaian tujuan dan sasaran organisasi. Mullins mengutip Reddin yang mengatakan, "managerial effectiveness has to be defined in terms of output rather than input, by what a manager achieves rather than by what he does." Efektivitas manajerial didefinisikan sebagai hasil keluaran daripada masukan, dengan apa yang manajer hasilkan daripada yang manajer kerjakan. Selanjutnya John R. Schermerhorn (2011:15) mengatakan "effective manager succesfully help others achieve both high performance and satisfaction in their work." Manajer yang efektif membantu yang lain mendapatkan keduanya dari kinerja yang tinggi dan kepuasan kerja mereka. Manajer dengan sukses dapat membantu bawahan untuk agar bawahan mengerjakan pekerjaan yang menghasilkan kinerja yang tinggi dan mereka akan merasa puas dengan pekerjaan mereka. Setiap individu memiliki kemampuan untuk menjadi pemimipin yang efektif. Kepala sekolah yang melaksanakan pekerjaan manajerial secara efektif dapat diketahui dari ketepatan pelaksanaan tugas untuk mencapai tujuan-tujuan sekolah yang telah ditetapkan. Perencanaan tujuan tidak terlepas dari fungsi manajemen kepala sekolah merencanakan jenis dan jumlah kegiatan, mengatur tata kerja seperti pembagian tugas dan wewenang, melaksanakan keg iatan dan mengevaluasi kelancaran kegiatan. Kepala sekolah juga dituntut untuk memiliki kepribadian yang kuat, dinamis dan enerjik dan senantiasa membangun komunikasi yang baik dengan seluruh anggota sekolah sehingga lebih mudah mengembangkan dan memajukan sekolah.

Dari berbagai kajian konsep yang telah diuraikan dapat disintesiskan bahwa efektivitas manajerial adalah ketepatan penggunaan sumber daya dalam melaksanakan fungsi manajemen pada pencapaian tujuan organisasi dengan indikator alokasi sumber daya, terpenuhinya tujuan, pengembangan rencana, koordinasi aktivitas kerja, dan pengawasan umum.

\section{Kewenangan}

Kewenangan berkaitan dengan kekuasaan yang dimiliki oleh pimpinan atau pejabat dalam suatu organisasi. Pengertian kewenangan adalah hak yang dimiliki pimpinan atau pejabat tertentu untuk mengambil keputusan, melakukan tindakan atau meninggalkan suatu tindakan. Fred Luthans (2008:281) mengatakan, "authority is the right to manipulate or change others." Otoritas adalah hak untuk merubah yang lain. Kewenangan memberikan sumber kekuasaan pada seseorang. Luthans dengan berdasarkan pada teori Barnard menyatakan, "authority as the character of a communication in a formal organization by virtue of which it is accepted by a contributor to or member of the organization as a governing the action he contributes." Barnard mendefinisikan otoritas atau kewenangan sebagai karakter dari komunikasi dalam organisasi formal dimana hak itu diterima oleh anggota organisasi sebagai kontribusi kekuasaan. 
Ivancevich (2008:321) mengatakan, "authority is the ability to influence others based on the perceiveid power of one's position and role within an organization." Menurutnya kewenangan atau otoritas adalah kemampuan mempengaruhi orang lain karena adanya kekuasaan yang dipersepsikan dari suatu jabatan dan peran tertentu dalam sebuah organisasi. James L. Gibson (2009:291) mengatakan, "authority is a formal power that a person has because of the position in the organization." Kewenangan adalah kekuasaan formal yang dimiliki seseorang karena posisinya dalam organisasi. Artinya organisasi mengizinkan individu yang memegang jabatan tertentu untuk mempengaruhi individu-individu lainya. Dalam organisasi kekuasaan terbagi dalam dua kategori, kekuasaan interpersonal dan kekuasaan struktural. John French and Bertram Raven dalam Gibson mengklasifikasikan, "five interpersonal bases of power: legitimate, reward, coercive, expert, and referent. Legitimate power is similar to the concept au thority." Bahwa lima sumber kekuasaan interpersonal adalah legitimasi, imbalan, koersif, keahlian, dan referensi. Dan kekuasaan Legitimasi inilah yang disebut sebagai otoritas atau kewenangan.

Gary Yukl (2010:199) mengatakan, "authority involves the rights, preogratives, and duties assosiated with particular position in an organization." Kewenangan melibatkan hak, hak istimewa, kewajiban, dan tugas dengan posisi tertentu dalam sebuah sistem organisasi atau sosial. Kewenangan pemimpin biasanya meliputi hak untuk membuat keputusan khusus untuk organisasi. Selanjutnya Gary Yukl memberikan panduan untuk menggunakan kekuasaaan yang memiliki legitimasi: (1)Make polite,clear reques; (2) explain the reasons for a request; (3) don't exceed your scope of authority; (4) verify authority is necessery; (5) follow propper channels; (6) follow up to verify compliance and (7) insist on compliance if appropriate. Panduan untuk menggunakan wewenang yang memiliki legitimasi: (1) melakukan permintaan dengan cara sopan dan jelas, (2) menjelaskan alasan dari permintaan, (3) jangan keluar dari cakupan wewenang (4) verifikasikan wewenang jika perlu, (5) ikuti jalur yang jelas, (6) menindaklanjuti untuk verifikasi kepatuhan dan (7) mendesak kepatuhan jika perlu. Dari pembahasan berbagai kajian konsep yang diuraikan dapat disintesiskan bahwa kewenangan adalah kekuasaan formal yang dimiliki seseorang untuk mempengaruhi bawahan dalam organisasi dengan ind ikator penggu naan kekuasaan, adanya ketegasan, memiliki integritas dan memiliki kesetiaan.

\section{Pengambilan Keputusan}

Pengambilan Keputusan adalah proses manajerial yang yang penting yang dijalani setiap individu. Pengambilan keputusan yang efektif adalah partisipasi yang mempengaruhi organisasi dan individu. Luthans (2006:403) mengemukakan, "pengambilan keputusan didefin isikan secara universal sebagai pemilihan alternatif." Menurut John L. Schermerhorn (2011:157)," a decision is a choice among possible alternative cources of action." Keputusan adalah sebuah pilihan antara alternatif-alternatif yang mungkin menjadi tindakan. Kreitner dan Kinicki (2010:336) mengatakan, "decision making entails identifyng and choosing alternative solutions that lead to a desire state of affairs." Pengambilan keputusan memerlukan identifikasi dan memilih solusi alternatif yang akan mengarahkan kepada keadaan dari urusan yang diinginkan. Colquitt (2009:256) mengatakan, "decision making refers to the process of generating and choosing from a set of alternatives to solve a problem." Pengambilan keputusan merupakan proses memilih berbagai alternatif untuk pemecahan masalah. Pengambilan keputusan adalah hal yang sangat penting dan dapat memberikan pengaruh yang signifikan terhadap kemajuan organisasi. Malcolm Cook, Jan Noyes dan Yvonne (2007:3) mengatakan, "research into decision making has traditionally focused on how people as individuals chose 
among alternatives and specifically about how they go about finding the best alternatives or making the 'right' decisions." 55 Penelitian tentang pengambilan keputusan secara alami terpusat kepada bagaimana seseorang sebagai individu memilih alternatifalternatif dan khususnya tentang bagaimana mereka dapat menemukan alternatif terbaik atau membuat keputusan yang 'benar'.

Menurut Robbins (2011:210), keputusan yang seperti itu memiliki enam langkah model pengambilan keputusan, These decisions follow a six step rational decision making model (1) define the problem, (2) identify the decision criteria, (3) allocate weights to the criteria, (4) develop the alternatives, (5) evaluate the alternatives and (6) select the best alternatives. Pertama define the problem adalah menemukan masalah. Dalam hal ini diperlukan untuk menentukan kebutuhan untuk suatu keputusan, sehingga diperlukan menemukan masalah yang utama dalam organisasi. Kedua identify decision criteria, yaitu mengidentifikasi kriteria keputusan yang dibuat berdasarkan prioritas guna memperoleh keputusan yang tepat. Ketiga allocate weights to criteria yaitu menemukan bobot pada sejumlah kriteria. Keempat develop alternatives, yakni mengembangkan berbagai kemungkinan pilihan. Kelima evaluate alternatives, maksud nya penilaian terhadap alternatif dengan menilai berbagai kekuatan dan kelemahan serta membandingkannya dengan kriteria prioritas yang telah dibuat. Keenam select the best alternative, memilih alternatif terbaik dari berbagai pilihan sesuai kriteria yang telah dibuat tanpa melupakan analisis kuantitas.

Berdasarkan uraian konsep sebelumnya dapat disintesiskan bahwa pengambilan keputusan merupakan tindakan memilih alternatif dala $\mathrm{m}$ pemecahan masalah untuk mencapai tujuan organisasi dengan indikator identifikasi masalah, analisis alternatif, pemilihan prioritas, penetapan keputusan dan evaluasi keputusan.

\section{METODE}

Penelitian ini dilaksanakan pada SMA Swasta di Jakarta Utara dengan unit analisis kepala SMA Swasta di Jakarta Utara. Waktu penelitian berlangsung bulan April 2012 sampai Juli 2012. Penelitian ini menggunakan metode survey dengan menggunakan pendekatan analisis jalur. Populasi dalam penelitian adalah kepala sekolah- kepala sekolah pada Sekolah Menengah Atas Swasta di Jakarta Utara berjumlah 60. Sampel sebanyak 52 kepala Sekolah Menengah Atas Swasta di Jakarta Utara yang dianggap representatif mewakili semua Kepala Sekolah Menengah Atas Swasta di Jakarta Utara.

\section{HASIL PENELITIAN DAN PEMBAHASAN}

\section{Pengaruh Kewenangan terhadap Efektivitas Manajerial}

Berdasarkan hasil analisis disimpulkan bahwa terdapat pengaruh langsung yang signifikan kewenangan terhadap efektivitas manajerial. Dengan demikian dapat ditafsirkan bahwa semakin baik kewenangan digunakan, semakin baik efektivitas manajerial kepala sekolah, sebaliknya jika kewenangan menurun maka akan menurun pula efektivitas manajerial kepala sekolah. Hal ini sesuai dengan teori yang dikemukakan oleh Ivanchevich (2008:454) bahwa: Managers who have relatively high authority can exercise more autonomy and thus satisfy their desires to participate in problem solving. This autonomy can lead to managerial creativity and ingenuity, which contribute to the adaptiveness and depelopment of organization managers. Para manajer yang memiliki kewenangan yang relatif tinggi dapat menjalankan lebih banyak hasrat kemandirian dan dengan demikian memuaskan hasrat-hasrat mereka untuk ikut serta memecahkan masalah. Kemandirian ini dapat menghasilkan kreativitas dan 
kecakapan manajerial yang memberikan andil terhadap kemampuan beradaptasi serta untuk mengembangkan organisasi dan pengembangan manajer. Seperti penelitian yang telah dilakukan oleh Jeffrey Pfeffer. Ia mengidentifikasi beberapa pertimbangan yang dianggap penting dalam menggunakan kekuasaan untuk melakukan pengelolaan yang efektif. Menurutnya, "however effective you are as a manager, increasing your influence will further increase your effectiveness." Seberapa pun efektifnya seseorang sebagai seorang manajer, akan tetap dapat meningkatkan efektivitasnya dengan men ingkatkan pengaruh yang dimiliki. Dengan demikian terdapat pengaruh langsung antara kewenangan dan efektivitas manajerial.

\section{Pengaruh Pengambilan Keputusan terhadap Efektivitas Manajerial}

Berdasarkan hasil analisis disimpulkan bahwa terdapat pengaruh langsung yang signifikan pengambilan keputusan terhadap efektivitas manajerial. Dengan demikian dapat dijelaskan bahwa semakin baik pengambilan keputusan yang dilakukan, semakin tinggi efektivitas manajerial kepala sekolah. Sebaliknya jika pengambilan keputusan menurun, akan semakin menurun pula efektivitas manajerial kepala sekolah. Seperti dijelaskan Jennifer M. George (2005:471), "good decision help an individual, group or organization be effective. Bad decision hinder effectiveness and result in poor performance and negative attitudes at all organizational levels." Keputusan yang baik membantu individu, kelompok, ataupun organisasi menjadi efektif. Keputusan yang buruk menyembunyikan efektifitas dan behkan unjuk kerja yang buruk dalam setiap tingkat organisasi. Jadi proses pengambilan keputusan yang tepat akan menghasilkan efektivitas manajerial. Ivanchevich (2008:381)mengatakan, "the quality of the decisions that managers make is the yardstick of their effectivenes." Kualitas dari keputusan yang dibuat manajer adalah ukuran dari keefektifan mereka. Sehingga dapat disimpulkan terdapat pengaruh langsung antara pengambilan keputusan dengan efektivitas manajerial.

\section{Pengaruh Kewenangan terhadap pengambilan keputusan}

Berdasarkan hasil analisis disimpulkan bahwa terdapat pengaruh langsung yang signifikan kewenangan terhadap pengambilan keputusan. Dari uraian di atas dapat disimpulkan bahwa kewenangan dapat mempengaruhi langsung pengambilan keputusan. Oleh sebab itu diperlukan kewenangan yang tinggi agar kepala sekolah memiliki hasil pengambilan keputusan yang baik. Menurut Ivancevich (2008:381) "a person or subunit with power can influence how the decision making process occurs, what alternatives are considered, and when a decision is made." Seorang pemimpin yang memiliki kekuasaan dapat mempengaruhi jalannya proses pengambilan keputusan, mempengaruhi alternatif-alternatif yang dipertimbangkan dan mempengaruhi kapan keputusan diambil. Seorang pemimpin sebagian besar waktu dan perhatian, maupun pikirannya dipergunakan untuk mengkaji proses pengambilan keputusan. Keputusan dari seorang pemimpin tidak muncul secara tibatiba, tetapi berlangsung sebagai sebuah proses. Dalam kenyataannya proses itu mungkin terjadi dalam diri pemimpin sendiri. Mungkin pula ditetapkan dengan mengikutsertakan anggota organisasi sekolah. Sehubungan dengan itu secara konvensional harus diterima kenyataan bahwa pengambilan keputusan adalah 
wewenang pimpinan tertinggi dari sebuah organisasi. Dengan kata lain pengambilan keputusan yang akan diwujudkan menjadi kegiatan kelompok atau organisasi merupakan hak dan kewajiban pimpinan.

Menurut Gibson (2009:13) "managerial decision making is permeated by ethical issues. Managers have power and authority; when these factor exist, there is potential for wrong and right, good and evil." 29 Kegiatan manajerial pengambilan keputusan menjadi isu penting bagi organisasi. Manajer memiliki kekuasaan dan kewenangan, ketika faktor ini ada, maka akan berpotensi untuk keputusan yang salah dan benar, baik dan tidak. Jadi sebuah keputusan ditentukan oleh tepatnya kewenangan yang digunakan. Kewenangan seorang pemimpin terhadap pengambilan keputusan mengindikasikan jumlah kekuasaan yang dimilikinya. Individu-individu yang dapat mempengaruhi pengambilan keputusan dan hasil akhirnya mungkin memiliki kewenangan atau otoritas. Dengan demikian dapat disimpulkan bahwa terdapat pengaruh langsung positif kewenangan dengan pengambilan keputusan.

\section{PENUTUP}

\section{Kesimpulan}

Berdasarkan uraian dan hasil analisis, maka dapat diambil beberapa kesimpulan sebagai berikut:

1. Terdapat pengaruh langsung positif kewenangan terhadap efektivitas manajerial, artinya semakin tinggi kewenangan kepala sekolah maka akan semakin meningkat efektivitas manajerial kepala sekolah. Sedangkan jika kewenangan kepala sekolah menurun, maka efektivitas manajerial kepala sekolah akan menurun.

2. Terdapat pengaruh langsung positif pengambilan keputusan terhadap efektivitas manajerial, artinya semakin tingg i tingkat pengambilan keputusan kepala sekolah maka akan semakin meningkat efektivitas manajerial kepala sekolah. Sedangkan jika tingkat pengambilan keputusan kepala sekolah menurun akan menurun juga efektivitas manajerial kepala sekolah.

3. Terdapat pengaruh langsung positif kewenangan terhadap pengambilan keputusan, artinya semakin tinggi kewenangan kepala sekolah semakin tinggi tingkat pengambilan keputusan kepala sekolah, sedangkan jika kewenangan kepala sekolah menurun akan menurun juga tingkat pengambilan keputusan kepala sekolah.

\section{Implikasi}

Berdasarkan hasil kesimpulan yang dikemukakan dapat dikatakan bahwa temuan penelitian ini menginformasikan adanya pengaruh kewenangan dan pengambilan keputusan terhadap efektivitas manajerial kepala sekolah.

Upaya yang perlu dilakukan kepala sekolah dalam meningkatkan efektivitas manajerialnya diantaranya dengan memperbaiki tingkat kewenangan dan pengambilan keputusan dalam sekolah.

\section{Mempergunakan Kewenangan Kepala Sekolah}

Sebuah organisasi sekolah dipimpin oleh seorang kepala sekolah yang diberikan kewenangan untuk mengelola manajemen sekolah. Kewenangan itu perlu dijalankan dengan sebaik baiknya. Pada umumnya di sekolah swasta, kepala yayasan lebih berperan dalam pengelolaan sekolah. Dalam situasi seperti ini kepala 
sekolah tidak boleh sepenuhnya menyerahkan pengelolaan kepada pihak yayasan. Karena kepala sekolah lah yang lebih memahami keadaan organisasi, sehingga kepala sekolah seharusnya lebih mempergunakan kewenangannya untuk pengembangan dan pemberdayaan sekolah. Sebagai manajer suatu lembaga pendidikan, kepala sekolah berwenang mengelola administrasi keuangan sekolah serta pengembangan sarana dan prasarana sekolah. Sehingga pelaksanaan kegiatan sekolah akan arif dan bijaksana. Kepala sekolah seharusnya mempergunakan kewenangan untuk mengelola organisasi sekolahnya dengan kemandiriannya, yang akan men ingkatkan kreativitas dan kecakapan kemampuan manajerialnya. Tidak merasa tertekan dengan aturan dari atas dalam hal ini adalah pihak yayasan. Sehingga tidak akan terjadi sekolah sekolah swasta yang ditutup karena keinginan pihak yayasan.

Dalam melaksanakan kewenangan, kepala sekolah hendaknya tegas dan menyakinkan. Dalam situasi yang mendesak, sangat penting permintaan dilakukan dengan cara yang tegas daripada dengan cara yang sopan. Perintah langsung dengan nada memerintah terkadang perlu untuk mengejutkan bawahan agar melakukan tindakan segera dalam situasi mendesak. Keragu-raguan akan membuat bawahan bingung dan akan beresiko kehilangan pengaruh pada bawahan. Hal yang ditolak oleh bawahan dalam melaksanakan permintaan kepala sekolah akan menurunkan kewenangan pemimpin dan meningkatkan kemungkinan ketidakpatuhan dimasa yang akan datang. Sehingga dapat dikatakan bahwa dalam menjalankan organisasi diperlukan kewenangan dari seorang pemimpin yang tegas untuk dapat menggerakkan semua sumber daya yang ada pada organisasi agar organisasi berjalan efektif. Kepala sekolah perlu menggunakan kewenangannya untuk menggerakkan sumber daya yang ada di sekolah agar efektif. Akan tetapi posisi kewenangan kepala sekolah yang terlalu banyak atau terlalu sedikit mungkin akan merusak. Jadi akan efektif kekuasaan jika digunakan sesuai dengan kewenangannya.

\section{Meningkatkan Pengambilan Keputusan Kepala Sekolah}

Seorang kepala sekolah sebagian besar waktu dan perhatian, maupun pikirannya dipergunakan untuk mengkaji proses pengambilan keputusan. Pengambilan keputusan menjadi tugas utama yang harus dilaksanakan. Perilaku dan cara kepala sekolah dalam pola pengambilan keputusan sangat mempengaruhi perilaku dan sikap dari para pengikutnya. Hal ini sangat menentukan kinerja sekolah untuk mencapai tujuannya. Oleh sebab itu pengambilan keputusan yang dilakukan oleh kepala sekolah haruslah didasarkan untuk tujuan organisasi sekolah.Sebab pengambilan keputusan adalah hal yang sangat penting dan dapat memberikan pengaruh yang signifikan terhadap kemajuan organisasi.

Dalam pengambilan keputusan sebaiknya kepala sekolah berkoordinasi dengan anggota organisasi sekolah yang lain dan tidak mengambil keputusan sendiri. Kepala sekolah hendaknya menelusuri pengalaman kerja sebelumnya dalam hal pengambilan keputusan. Dalam hal pemilihan alternatif, kepala sekolah memilih keputusan yang berdasarkan prioritas untuk tujuan organisasi sekolah dan kepentingan anggota organisasi sekolah, bukan hanya untuk kepentingan pribadi semata 


\section{Saran}

Berdasarkan hasil penelitian dan implikasi, maka dalam rangka meningkatkan kewenangan dan pengambilan keputusan direkomendasikan beberapa langkah tindak lanjut sebagai berikut:

1. Diharapkan para kepala sekolah di wilayah Jakarta Utara dan wilayah DKI Jakarta pada umumnya untuk meningkatkan kewenangan dan pengambilan keputusannya guna meningkatkan efektivitas manajerial kepala sekolah

2. Diharapkan pemerintah tingkat suku dinas memperhatikan faktor kewenangan dan pengambilan keputusan kepala sekolah dalam meningkatkan efektivitas manajerial kepala sekolah, tidak hanya memperhatikan faktor kognitif kepala sekolah saja.

3. Diharapkan adanya kegiatan berupa pelatihan atau pembinaan bagi kepala sekolah dengan memberikan pengetahuan untuk meningkatkan kewenangan dan pengambilan keputusan dalam rangka meningkatkan efektivitas manajerial kepala sekolah. 


\section{DAFTAR RUJUKAN}

Colquitt., Jason A. Lepine, Jeffery A. and Weeson Michael J. Organizational Behaviour : Improving Performance and Commitment in The Workplace. NewYork: McGraw-Hill, 2009.

Cook, Malcolm. Noyes, Jan and Masakowski, Yvonne. Decision Making in Complex Environment. USA: Ashgate Publishing Company, 2007.

Daft, Richard L. New Era of Management. Canada : Cengage learning, 2010.

Gibson, James L., et al. Organizations : Behaviour, structure, Processes. Singapore : McGraw-Hill, 2009.

George, Jennifer M and Jones, garreth R. Understanding and Managing Organizational Behaviour. New Jersey: Pearson Educational International, 2005.

Ivancevich, John M. Konopaske, Robert and Matteson, Michael T. Organizational Behaviour and Management. New York:McGrawHill,2008.

Kreitner, Robert and Kinicki, Angelo. Organizational Behaviour. New York: McGrawHill, 2010.

Luthans, Fred. Organizational Behaviour. Singapore: McGraw-Hill, 2008. Luthans, Fred. Perilaku Organisasi. Yogyakarta: Andi, 2006.

Mullins, Laurie J. Management and Organisational Behaviour. England : Prentice Hall, 2005.

Robbins, Stephen P. and Judge A. Timothy. Organizational Behaviour. New Jersey: Pearson, 2011.

Robbins, Stephen P. and Coulter, Mary. Management. New jersey: Pearson Education, 2007.

Schermerhorn, John R Jr., et al. Organizational Behaviour. Asia : John Willey\&Son, 2011.

Usman, Husaini. Manajemen Teori, Praktik, dan Riset Pendidikan. Jakarta: Bumi Aksara, 2009.

Yukl, Gary. Leadership in Organization. New Jersey: Pearson, 2010. 